The Research Journal of the Costume Culture

[Original Article]

Received February 13, 2017

Revised April 18, 2017

Accepted April 22, 2017

${ }^{\dagger}$ Corresponding author

(ksa@wku.ac.kr)

ORCID

WOONG SUB LEE

http://orcid.org/0000-0003-2721-5039

Sun Ah Kim

http://orcid.org/0000-0003-1288-060X

This paper is a part of a doctoral dissertation.

\section{Development of standard shoe-lasts that reflect BMI and foot characteristics of senior generation women}

\author{
Woong-Sub Lee and Sun-Ah $\mathrm{Kim}^{\dagger}$ \\ Dept. of Fashion Design \& Apparel Industry, Wonkwang University, Korea
}

\section{여성 시니어 세대 BMl와 발 특성에 따른 구두용 표준 라스트 개발}

\author{
이 웅 섭 · 김 선 아 ${ }^{+}$
}

원광대학교 패션디자인산업학과

\begin{abstract}
The purpose of this study is to analyze the body mass index(BMI) and foot characteristics of senior-generation women and to use those values to develop a standard shoe last for producing shoes that best fit the foot of senior-generation women. In order to develop a standard shoe last that reflects the BMI and foot characteristics of senior-generation women, I analyzed the morphometric characteristics of feet by conducting descriptive statistics for each item. The foot characteristics based on BMI were analyzed by conducting ANOVA and Duncan's tests via the foot's measured values. Subsequently, I developed a standard shoe last reflecting the BMI and the foot characteristics of senior-generation women by applying all those values. Senior-generation women showed significant differences among three groups based on BMInormal weight, overweight, and obese - in all the items except for medial ball width and toe 5 angle. Through these values, I realized that as the value of the BMI becomes higher, the size of the foot becomes larger. This suggests that as a woman's weight increases or decreases, her shoes need to be replaced as well as her clothes. Deviations in the toe-side parts of the shoe could cause deformation of the foot. If someone keeps wearing shoes produced using a shoe last with a large deviation, she risks developing foot conditions like hallux valgus. This situation points to the need for shoe manufacture that utilizes a standard shoe last that reflects the BMI and foot characteristics of the senior generation.
\end{abstract}

Keywords: female senior generation(여성 시니어 세대), BMI(체질량지수), senior fashion(시니어 패션), shoe-last(슈라스트)

\section{Introduction}

20세기 이후 인간의 평균 수명 연장 및 저출산 등과 같은 사회적 현상은 인구의 고령화를 불러일으켰다. 세계적으로 인구의 증가 추세가 계속되고 있으며, 한국의 고령화 속도 또한 빠르게 진행되고 있다. Statistics Korea(2015)에 따르면 65세 이 
상의 노인 인구 비율은 2000 년도 $7.1 \%$ 에 도달하여 고령화 사회에 진입하였고, 2018년에는 고령사회가 될 것으로 전망하였다. 고령화 사회로의 변화 속에 시니어 세대라는 새로운 소비자층이 등장하게 되었 다(Kim, 2011). 시니어 세대 소비자의 증가는 시니어 대상의 제품과 서비스의 증가로 이어지고, 다양한 실 버산업의 발전을 가져왔다. 시니어 세대를 위한 실버 산업으로는 요양서비스가 가장 높게 나타났으며, 그 외 의료기기, 금융, 식품, 의류 등의 다양한 실버산업 이 발전되고 있다(Ko, 2012).

실버산업의 발전은 시니어 세대의 세분화된 성향 과 특징을 파악하기 위한 마케팅 연구 증가로 이어지 고 있으나, 시니어 세대를 위한 의복연구는 미비하고, 이들의 활동과 안전에 있어 가장 중요한 신발과 관련 된 연구는 더욱 더 부족한 실정이다. 현재까지 이루 어진 시니어 세대 의복연구들은 대부분 상하의, 특수 복, 스카프 등의 연구로 이루어져 있으며, 신발과 관 련된 연구는 발을 대상으로 하는 기초연구에 불과하 다(Lee \& Kim, 2016). 시니어 세대의 대부분이 발에 불편함을 느끼거나, 발 질환을 격고 있으며, 그 원인 중 하나로 발에 맞지 않는 신발을 들 수 있다(Kim, 2015). Frey, Thompson, Smith, Sanders, and Horst$\operatorname{man}(1993)$ 의 연구에 따르면, '많은 여성이 실제 발에 비해서 작은 신발을 신어 통증을 호소하였으며, 어떤 형태로든 발의 변형을 가지고 있다'고 하였다. 이는 발과 상이한 라스트로 제작된 신발을 착용하여 나타 나는 현상으로 볼 수 있으며, 이러한 발의 변형은 청 소년보다 시니어 세대에게 더욱 빈번하게 일어나고 있다.

Lee(2004)는 체형을 나타내는 BMI에 따라서도 발 치수에 대한 볼너비와 볼거리 등 여러 항목에서 치수 의 차이가 있음을 보고하였고, $\operatorname{Shin}(2008)$ 은 BMI와 발의 유형에 밀접한 상관관계가 있다고 하였다. 이러 한 문제점에도 불구하고, 시니어 세대의 발에 대한 형태와 분류에 관한 연구는 다소 이루어지고 있으나, 발에 맞는 신발을 위해 반드시 필요한 라스트 개발 연구는 전무한 실정이다.

이에 본 연구는 시니어 세대의 발에 잘 맞는 신발 제작을 위한 일환으로 여성 시니어 세대의 체형과 특 징을 나타내는 $\mathrm{BMI}$ 와 발의 특성을 분석하고, 이에 따른 구두용 표준 라스트를 개발하고자 한다. 또한
연구 결과를 바탕으로 시니어 세대의 신발 제작을 위 한 직접적인 정보와 방향을 제시하는데 본 연구의 의 의가 있다.

\section{Background}

\section{Senior generation}

고령화는 한 나라의 총인구에 대한 노인 인구의 상 대적인 증가를 뜻하는 것으로 전체 인구 대비 노인의 인구비율이 점진적으로 증가하는 상태를 말한다(Park, 2010). UN은 노인의 기준을 65 세로 정하고, 한 나라 전체 인구 중 65 세 이상의 인구비율이 7 14\% 미만인 사회를 고령화 사회라 하였으며, $14 \sim 20 \%$ 미만인 사 회를 고령사회, $20 \%$ 이상인 사회를 초고령 사회 (super-aged society)로 분류하고 있다("Median age", 2016). 고령사회의 진입 속도는 프랑스 115년, 스웨 덴 85년, 미국 71년, 영국 41년이 걸렸으며, 한국은 약 22년에 불과할 것으로 예상하고 있다(Ryu, Park, $\&$ Lee, 2004). 한국의 고령화 속도가 다른 선진국들 에 비해 매우 빠르게 나타나고 있어, 향후 시니어 세 대의 활동과 생활반경이 빠르게 확대될 전망이다.

시니어 세대라는 용어는 실버세대라는 단어와 함 께 사용되기도 하나, 일반적으로 실버는 70대 이상을 지칭하는 말로 사용되고 있으며, 시니어는 50 대의 중 장년층부터 60 대까지의 노년층을 포괄하는 의미로 사용된다(Kim, 2015). 시니어 세대는 문화, 사회, 정 서 등 사회 환경에 따라 차이가 있을 수 있으며, 일반 적으로 생물학적이나 정신적 기능이 쇠약하고, 사회 적 면에서 지위와 역할기능이 약화된 연령층으로 보 는 시각도 존재한다(Ko, 2014). 실버는 사전적 의미 인 노인이라는 단어가 갖는 부정적 이미지를 없애기 위해 고안된 용어로서 직장에서 퇴직한 뒤 연금이나 퇴직금 등으로 생활하거나 자식들이 주는 용돈으로 여생을 보내는 노인들을 일컫는다("New Silver Generation", n.d.).

그러나 노인들은 실버라는 단어를 좋게 생각하고 있지 않으며, 노인 단체들이 실버라는 말 대신 시니 어로 불러 달라고 공식 요청한 사례가 있기도 하였다 (Park, Kim, \& Lee, 2003). 한국의 노인복지관 이용 연령은 60 세로 되어 있으며, 노동법상 정년퇴직 연령 은 55세, 생활보호법상의 노인은 65 세로 규정하고 있 
어(Ryu et al., 2004), 시니어 세대를 정의할 수 있는 연령대 기준이 서로 다르게 적용되어지고 있음을 알 수 있다. 한편, 국가지표체계에서의 고령자 통계는 65 세 이상의 인구에 대해서만 통계를 내고 있으며(Statistics Korea, n.d.), 고용노동부의「고용상 연령차별 금지 및 고령자고용촉진에 관한 법률」(Enforcement decree of the act, 2016)에서는 고령자를 55세 이상, 준고령자를 50세 이상부터 정의하고 있음을 알 수 있 다. 이에 본 연구에서는 국내 고령자고용법을 근거하 여 준고령자인 50세 이상의 연령대를 시니어세대로 정의하여 연구를 진행하고자 한다.

\section{BMl}

Body Mass Index(BMI)는 인간의 신체적 비만도를 나타내는 지수이며, Koreas Society for the Study of Obesity(KSSO)에서는 BMI가 체중 $(\mathrm{kg})$ 을 신장(meter) 의 제곱으로 나눈 값으로, 대다수 인구집단에서 체지 방량과 상관관계가 높아 체중 및 신장을 이용한 지수 중 가장 널리 사용되는 방법이다(KSSO, 2012). International Association for the Study of Obesity(IASO) 에서는 $\mathrm{WHO}$ 의 아시아지역의 과체중 기준을 $\mathrm{BMI}$ $23 \mathrm{~kg} / \mathrm{m}^{2}$ 이상, 비만의 기준을 $25 \mathrm{~kg} / \mathrm{m}^{2}$ 이상으로 정 의하고 있다(IASO, 2000). 이러한 기준은 한국 성인 이 BMI $25 \mathrm{~kg} / \mathrm{m}^{2}$ 를 기점으로 하여 비만 관련 질환이 1.5 2배 가량 증가하는데 근거를 두고 있다. 한국인 은 $\mathrm{BMI}$ 가 가장 낮은 저체중이 BMI $18.5 \mathrm{~kg} / \mathrm{m}^{2}$ 미만 을 기준으로 하며, 정상체중은 $18.5 \mathrm{~kg} / \mathrm{m}^{2}$ 부터 22.9 $\mathrm{kg} / \mathrm{m}^{2}$ 까지, 과체중은 $23 \sim 24.9 \mathrm{~kg} / \mathrm{m}^{2}, 1$ 단계 비만은 $25 ~ 29.9 \mathrm{~kg} / \mathrm{m}^{2}, 2$ 단계 비만은 $\geq 30 \mathrm{~kg} / \mathrm{m}^{2}$ 을 기준으 로 하고 있다(KSSO, 2012).

$\mathrm{BMI}$ 는 인간의 생활과 건강에 밀접한 관계가 있는 것으로 알려져 있다. $\mathrm{BMI}$ 의 증가에 따라 고혈압이 증가하며, 40 대보다 50 대의 연령에서 높은 고혈압 경 향을 보이며(Ko, 2007), 저체중을 기준으로 $\mathrm{BMI}$ 의 증가에 따라 고혈압이 증가하여 비만과 고도비만군 으로 갈수록 교차비는 급격하게 증가하는 경향을 보 였다(Yun, 2011). Kim, Kim, and $\operatorname{Han(2012)ㅇㅡㄴ~ㄴㅗㅇㅣㄴ~}$ 들의 계단 내려가기 보행 동작 연구에서 비만인 경우 정상인에 비해 힘의 중심을 후방으로 유지하려는 경 향을 보였으며, 계단 내려가기 보행 동작 시 빠른 보
행속도와 좌우 밸런스의 큰 흔들림 등으로 낙상에 대 한 불안감이 있는 것으로 보고하였다. Kang and Park (2014)의 BMI를 기준으로 한 노인의 안전성과 보행 기능에 대한 연구에서는 한쪽 다리의 발뒤꿈치에서 반대쪽다리의 발뒤꿈치까지 거리인 활보장이 정상체 중군이 과체중군보다 더 길게 나타났고, 양쪽 다리가 동시에 지면과 접촉하고 있는 양발지지기의 경우도 정상체중군이 과체중군보다 더 짧은 기간을 지지하 는 것으로 나타났다.

$\mathrm{BMI}$ 는 발과도 밀접한 관계가 있는 것으로 알려져 있으며, Lee(2004)는 BMI와 발치수는 유의한 상관관 계를 보인다고 하였다. 특히 시니어 세대의 BMI는 건강과 안전에 깊은 관련이 있으며, 발과의 관련성 또한 입증되고 있으나, $\mathrm{BMI}$ 를 고려한 라스트 및 신 발 개발 연구는 전무한 실정이다. 이에 본 연구는 $\mathrm{KSSO}$ 의 $\mathrm{BMI}$ 분류 지침에 따라 정상체중(18.5 22.9 $\left.\mathrm{kg} / \mathrm{m}^{2}\right)$, 과체중 $\left(23 \sim 24.9 \mathrm{~kg} / \mathrm{m}^{2}\right)$, 비만 $(25 \sim 30 \mathrm{~kg} /$ $m^{2}$ ) 집단의 특성을 반영한 표준 라스트를 개발하고 자 한다.

\section{Shoe-last}

라스트(LAST)는 발자국(footprint)이라는 앵글로 색 슨어의 "laest"에서 유래된 말로(Toeslayer dot, 2009), 화형(靴型), 신발골, 구두골, 운동화골 등으로 불리며, 신발을 만들 때 사용하는 발 모양의 틀을 말한다 (Kim, 2016). 라스트는 기본적으로 신발의 최종 길이 (length)와 너비(width), 토쉐입(toe shape) 등 신발의 전체적인 형태를 결정하는 역할을 하고 있으며, 신발 의 패턴(pattern)과 인솔(Insole), 아웃솔(Outsole) 제작 에도 사용되기에 신발 제조에 있어 가장 기본이 되는 요소라 할 수 있다. 국내에서 사용하는 라스트는 발 길이가 $5 \mathrm{~mm}$ 늘어날 때마다 라스트 길이 $5 \mathrm{~mm}$, 볼둘 레 $3.5 \mathrm{~mm}$, 볼너비 $1.2 \mathrm{~mm}$ 가 늘어나도록 하고 있다 (Lee, 2001).

프랑스에서 사용되는 Paris Point System은 사이즈 가 1 포인트씩 커질 때마다 라스트 길이가 $6.67 \mathrm{~mm}$ 늘 어나고, 볼 둘레는 $5 \mathrm{~m}$, 볼 너비는 $1.67 \mathrm{~mm}$ 씩 커지도 록 규정하고 있으며, 영국은 한 사이즈에 길이 8.46 $\mathrm{mm}$, 볼둘레 $6.35 \mathrm{~mm}$, 볼너비 $2.12 \mathrm{~mm}$ 가 커지도록 규 정하고 있다(Lee, 2004). 라스트는 제작하는 신발의 종류와 모양, 디자인에 따라 다른 형태와 종류를 가 
지고 있다. 플라스틱 라스트는 나무로 제작된 라스트 보다 오래 사용할 수 있으며, 라스트의 변형이 적어, 라스트의 수정 시 변형 및 보완에 용이해 많은 신발 제작업체에서 사용되고 있다. 폴리에틸렌(polyethylene)을 주원료로 사용하며, 고압의 증기나 정밀성이 요구되는 경우 알루미늄과 같은 금속의 라스트를 사 용하기도 한다(Lee, 2001).

표준 라스트는 국제규격(ISO, IEC), 지역규격(CE 등), 국가규격( $\mathrm{KS}, \mathrm{JIS}, \mathrm{IS}$ 등), 단체규격(브랜드) 등으 로 나뉘며, 국내외에서 다양한 표준화 규격이 존재한 다. 한국의 표준 라스트는 국가기술표준원에서 1981 년 6월 처음 제정하여 4번의 개정을 거쳐 지금의 $\mathrm{KS}$ G 3405 구두용 라스트로 규격화하였다. 그러나 한국 인의 평균 발 사이즈 등의 변화된 시대상을 전혀 반 영하지 못하고 있으며, 2001년에 개정된 이후 더 이 상의 개정 없이 20 년째 그대로 같은 내용과 데이터만 이 확인되고 있는 실정이다.

시대의 변화와 세분화된 소비자군의 발 특성에 따 른 새로운 표준 라스트 규격 설정은 매우 중요한 연 구분야이다. 특히 발의 변형이 심해지는 여성 시니어 세대의 라스트 또한 일반 성인 라스트와는 별도로 새 로운 라스트의 표준 규격이 요구되어진다. 이에 본 연구에서는 여성 시니어의 BMI와 발 특성을 함께 고 려한 구두용 표준 라스트를 설계 및 개발을 진행하고 자 한다.

\section{Research Methods}

\section{Research problem}

본 연구는 여성 시니어 세대를 대상으로 3차원 발 형상 데이터를 이용하여 $\mathrm{BMI}$ 에 따른 발의 특성을 분 석하고, 이를 활용한 구두용 표준 라스트를 개발하고
자 한다. 구체적 연구문제는 다음과 같다.

첫째, 여성 시니어 세대의 $\mathrm{BMI}$ 군집에 따른 발의 형태적 특성을 분석한다.

둘째, 회귀식을 통한 항목별 표준 라스트 설계값을 도출한다.

셋째, 설계값을 적용한 여성 시니어 세대 구두용 표준 라스트를 개발한다.

넷째, 개발된 표준 라스트와 비교라스트의 기준값 을 측정하고, 이를 비교분석한다.

\section{Subject}

본 연구는 여성 시니어 세대의 발 특성 분석을 위 해 국내 고령자고용법을 근거하여 50세에서 79세를 시니어로 정의하고, 연구대상을 선정하였다. 기술표 준원에서 실시한 인체치수조사사업 중 50세에서 79 세까지의 $3 \mathrm{D}$ 발 형상 데이터가 가장 정확하게 조사 된 제 5 차 인체치수조사사업의 여성 시니어 세대 416 명에 대한 3차원 발 형상 측정 데이터를 활용하였다. $\mathrm{KSSO}$ 의 $\mathrm{BMI}$ 분류 지침에 따라 정상체중(18.5 22.9 $\left.\mathrm{kg} / \mathrm{m}^{2}\right)$, 과체중 $\left(23 \sim 24.9 \mathrm{~kg} / \mathrm{m}^{2}\right)$, 비만 $(25 \sim 30 \mathrm{~kg}$ $m^{2}$ ) 집단을 분류하였으며, 정상체중군과 과체중군 및 비만군에 대한 집단 분류가 적절한지에 대한 검증 을 위해 분산분석과 Duncan's test를 실시하였다. 그 결과는 〈Table 1〉에서 보는 바와 같이 각 집단 간 유 의한 차이가 나타났다.

\section{Analysis of foot characteristics and BMI}

라스트 개발을 위한 설계 항목 추출을 위해 인체치 수조사에서 사용하는 40 개의 3차원 발 형상 데이터를 중심으로 선행연구를 참고하여 발길이, 발꿈치-발등 길이, 발꿈치-발목길이, 발너비, 볼거리, 내측볼너비, 외측볼너비, 발꿈치너비, 볼둘레, 발등둘레, 발목수직

$<$ Table 1> BMI distribution of study subjects

\begin{tabular}{|c|c|c|c|c|c|}
\hline \multirow[b]{2}{*}{ Construct } & \multicolumn{4}{|c|}{$\operatorname{BMI}\left(k g / m^{2}\right)$} & \multirow[b]{2}{*}{$F$-Value } \\
\hline & $\begin{array}{c}\text { Normal weight } \\
(<18.5 \sim 22.9)\end{array}$ & $\begin{array}{l}\text { Overweight } \\
(23 \sim 24.9)\end{array}$ & $\begin{array}{c}\text { Obesity } \\
(25 \sim \geq 30)\end{array}$ & $\begin{array}{l}\text { Average total } \\
\mathrm{N}(\%)\end{array}$ & \\
\hline $\begin{array}{c}\text { Average } \\
\mathrm{n}(\%)\end{array}$ & $\begin{array}{c}21.5 \mathrm{~kg} / \mathrm{m}^{2} \\
107(25.8)^{a}\end{array}$ & $\begin{array}{c}24.0 \mathrm{~kg} / \mathrm{m}^{2} \\
113(27.2)^{b}\end{array}$ & $\begin{array}{c}27.2 \mathrm{~kg} / \mathrm{m}^{2} \\
195(47.0)^{c}\end{array}$ & $\begin{array}{c}24.9 \mathrm{~kg} / \mathrm{m}^{2} \\
415(100)\end{array}$ & $519.41^{* * *}$ \\
\hline
\end{tabular}

${ }^{* * *} p \leq .001$, Duncan's test: $\mathrm{a}<\mathrm{b}<\mathrm{c}$ 
둘레, 발꿈치-발등둘레, 발꿈치-발목둘레, 볼높이, 엄 지발가락 높이, 새끼발가락측각도 등 총 16 개 항목을 최종 항목으로 추출하였다. 추출된 16 개의 항목을 중 심으로 여성 시니어 세대의 $\mathrm{BMI}$ 군집에 따른 발의 형태적 특성을 분석하였다. 통계분석은 SPSS Ver. 18 프로그램을 사용하였으며, 항목별 계측치의 평균 및 표준편차를 알아보기 위해 기술통계분석을 실시하였 으며, BMI군에 따른 차이를 알아보기 위해 분산분석 과 Duncan's test를 실시하여 발의 특성을 분석하였 다.

\section{Development and analysis of standard last}

여성 시니어 세대의 구두용 표준 라스트 개발을 위 한 항목별 설계값을 추출하기 위해 발길이를 독립변 수 $(x)$ 로 하고, 각각의 라스트 설계 항목을 종속변수 $(y)$ 로 하여 회귀식을 통해 표준 라스트 설계값을 추 출하였다. 설계값 추출을 위한 기준 사이즈는 산업체 에서 샘플 제작이나 그레이딩에 사용하고 있는 여성 표준 사이즈인 $235 \mathrm{~mm}$ 를 기준 사이즈로 설정하였다. 구두용 표준 라스트 개발 및 비교에 사용될 라스트 제작을 위해 한국산업규격 $\mathrm{KS} \mathrm{G} \mathrm{3405에서} \mathrm{제시한}$ 데이터를 적용한 실물 라스트를 제작하였다. 제작된 KS G 3405 라스트는 연구의 편의를 위해 "비교 라스 트”로 명명하였다. 최종 표준 라스트 제작을 위해 $\mathrm{KS}$ G 3405에서 제시하는 토박스, 굽높이, 토스프링 치수 와 회귀식에서 도출한 설계항목을 표준 라스트 제작 에 활용하였다. 블록 제작 단계와 황삭가공, 정삭가공 단계를 거쳐 여성 시니어 세대의 BMI에 따른 발 특 성을 반영한 구두용 표준 라스트를 개발하였다.

개발된 라스트의 기준값을 측정하기 위해 바닥면 을 기준으로 길이와 너비, 둘레항목 등의 라스트 기 준항목을 도출한다. 개발된 라스트의 분석을 위해 라 스트의 총길이, 굽높이, 토스프링, 뒤꿈치너비, 발목 수직둘레, 발등수직둘레, 볼수직둘레, 발저면너비, 볼 저면거리, 내측볼저면너비, 외측볼저면너비, 뒤꿈치 저면너비, 뒤꿈치-안쪽점저면길이, 뒤꿈치-가쪽점저 면길이 등 총 15 개 항목을 도출하였다. 라스트 기준 값의 비교 분석을 위해 비교 라스트와 최종 개발된 구두용 표준 라스트를 스캔하여 $3 \mathrm{D}$ 로 데이터화 하였 으며, 3차원 단면 계측을 위한 "EastLast3D" 프로그 램과 직접계측을 위한 "Vernier calipers"를 사용하여
라스트의 기준값을 측정하였다. 또한 $3 \mathrm{D}$ 비교 분석을 위해 3 차원 데이터를 통해 기준 데이터와 비교 데이 터의 치수 및 차이점을 시각적으로 나타낼 수 있는 "Geomagic Qualify 12" 프로그램을 활용하여 각각의 $\mathrm{BMI}$ 군에 따른 라스트를 3D Compare 방식으로 분석 하였다.

\section{Results and Discussion}

\section{Analysis of foot characteristic}

\section{1) Average and standard deviation by item}

여성 시니어 세대 416명에 대한 항목별 발 계측치 의 평균 및 표준편차는 〈Table 2 〉와 같다. 항목별 평 균값을 살펴보면, 발의 가장 큰 부분을 차지하는 발 길이는 $230.20 \mathrm{~mm}$, 발너비 $92.82 \mathrm{~mm}$ 의 결과를 보이고 있다. 이는 한국인 발 형상분류(Seong, Jung, \& Cho, 2006) 결과의 여성 평균 발길이 $232 \mathrm{~mm}$ 와 발너비 $92.82 \mathrm{~mm}$ 보다 짧은 평균값을 보였으며, 노년기 여성 의 발 형태분류(Park, 2003)에서 나타난 평균 발길이 $229.1 \mathrm{~mm}$ 와 발너비 $91.2 \mathrm{~mm}$ 보다는 큰 결과를 보였다. 볼둘레와 발꿈치-발목둘레의 계측치 평균값은 각각 $231.70 \mathrm{~mm}$ 와 $305.90 \mathrm{~mm}$ 의 결과를 보여, 노년기 여성 발 형태분류(Park, 2003)에 나타난 볼둘레 $226.6 \mathrm{~mm}$ 와 발꿈치-발목둘레 $301.3 \mathrm{~mm}$ 에 비해 큰 차이가 있어 조사대상자의 둘레항목 계측에 대한 논의가 더 필요 할 것으로 사료된다. 새끼발가락측각도는 $10.91^{\circ}$ 로 서, 한국인 여성 평균(Seong et al., 2006) 새끼발가락 측각도인 $9^{\circ}$ 보다 $2^{\circ}$ 에 가까운 차이를 보였다. 이는 나 이가 들어갈수록 새끼발가락이 안쪽으로 들어가는 것으로 발의 변형이 있음을 알 수 있는 결과이다. 발 계측치의 표준편차를 살펴보면 발목수직둘레가 가장 큰 편차를 보이고 있으며, 다음으로 발꿈치-발등굴레, 발꿈치-발목둘레, 볼둘레, 발등둘레 순으로 둘레항목 이 다른 항목에 비해 가장 큰 표준편차를 기록하였 다.

\section{2) Analysis of characteristics according to BMI}

여성 시니어 세대 BMI에 따른 발 특성을 분석하기 위해 $\mathrm{BMI}$ 를 군집으로 분산분석과 Duncan's test를 실 시한 결과, 내측볼너비와 새끼발가락측각도를 제외한 
$<$ Table 2> Analysis of foot characteristic

( $N=416$, unit: $\mathrm{mm})$

\begin{tabular}{l|c|c}
\hline \multicolumn{1}{c|}{ Measurement item } & Average & $\begin{array}{c}\text { Standard } \\
\text { deviation }\end{array}$ \\
\hline Foot length & 230.20 & 9.55 \\
\hline Heel-to-instep length & 128.41 & 6.97 \\
\hline Heel-to-ankle length & 98.54 & 6.33 \\
\hline Foot breadth & 92.82 & 5.19 \\
\hline Ball distance & 95.89 & 5.23 \\
\hline Medial ball width & 44.14 & 4.91 \\
\hline Lateral ball width & 48.77 & 4.03 \\
\hline Heel width & 62.78 & 3.51 \\
\hline Ball circumference & 231.70 & 11.33 \\
\hline Instep circumference & 226.07 & 10.42 \\
\hline Perpendicular ankle circumference & 247.57 & 19.51 \\
\hline Heel-to-instep circumference & 334.27 & 15.91 \\
\hline Heel-to-ankle circumference & 305.90 & 13.96 \\
\hline Ball height & 34.15 & 2.67 \\
\hline Toe 1 height & 22.42 & 2.01 \\
\hline Toe 5 angle ${ }^{\circ}$ & 10.91 & 4.02 \\
\hline
\end{tabular}

모든 항목이 유의한 차이가 있는 것으로 나타났다 (Table 3). 여성 시니어 세대 정상체중군의 평균값을 살펴보면, 새끼발가락측각도 $11.17^{\circ}$ 를 제외한 모든 계측 항목이 다른 $\mathrm{BMI}$ 군에 비해 모두 적은 수치로 나타났다. 이는 정상체중군의 발이 과체중군이나 비 만군에 비해 더 작고 낮은 특징을 가지고 있어, 보다 마른 형태의 발이라는 것을 알 수 있는 결과이다. 그 러나 사후검증인 턴컨테스트 결과에 의하면, 볼너비 외 7개 항목에 대해서는 정상체중군과 과체중군 집단 간 평균값의 차이를 보였으나, 발길이 외 6 개 항목(발 꿈치-발등길이, 발꿈치-발목길이, 외측볼너비, 발꿈치 너비, 발꿈치-발등둘레 및 볼높이)에 대해서는 두 집 단이 통계학적으로 동일한 수준의 평균값을 보여 집 단간 평균의 차이를 보이지 않은 것으로 분석되었다.

여성 시니어 세대의 과체중군은 내측볼너비가 44.62 $\mathrm{mm}$ 로 다른 체중군에 비해 가장 높은 수치를 나타냈 으나, 발꿈치-발등길이는 $126.50 \mathrm{~mm}$ 로 가장 낮게 나 타났다. 비만군은 내측볼너비 $44.37 \mathrm{~mm}$ 와 새끼발가락 측각도 $10.76^{\circ}$ 를 제외한 모든 항목에서 가장 높은 수 치를 기록하였으며, 새끼발가락측각도가 정상체중군

<Table 3> Average analysis of foot measurement

( $N=416$, unit: $\mathrm{mm})$

\begin{tabular}{l|c|c|c|c}
\hline BMI & $\begin{array}{c}\text { Normal weight } \\
(n=107)\end{array}$ & $\begin{array}{c}\text { Overweight } \\
(n=113)\end{array}$ & $\begin{array}{c}\text { Obesity } \\
(n=195)\end{array}$ & $F$-value \\
\hline Feot length & $228.87^{a}$ & $228.92^{a}$ & $231.66^{b}$ & $4.39^{*}$ \\
\hline Heel-to-instep length & $126.93^{a}$ & $126.50^{a}$ & $130.33^{b}$ & $15.01^{* * *}$ \\
\hline Heel-to-ankle length & $96.66^{a}$ & $98.01^{a}$ & $99.88^{b}$ & $9.82^{* * *}$ \\
\hline Foot breadth & $90.85^{a}$ & $93.04^{b}$ & $93.78^{b}$ & $11.72^{* * *}$ \\
\hline Ball distance & $93.78^{a}$ & $95.81^{b}$ & $97.10^{c}$ & $14.86^{* * *}$ \\
\hline Medial ball width & $43.19^{a}$ & $44.62^{b}$ & $44.37^{a b}$ & 2.78 \\
\hline Lateral ball width & $47.73^{a}$ & $48.47^{a}$ & $49.51^{b}$ & $7.37^{* * *}$ \\
\hline Heel width & $61.45^{a}$ & $62.15^{a}$ & $63.87^{b}$ & $20.61^{* * *}$ \\
\hline Ball circumference & $226.03^{a}$ & $231.30^{b}$ & $235.05^{c}$ & $24.43^{* * *}$ \\
\hline Instep circumference & $220.42^{a}$ & $225.55^{b}$ & $229.48^{c}$ & $29.94^{* * *}$ \\
\hline Perpendicular ankle circumference & $240.08^{a}$ & $245.15^{b}$ & $253.08^{c}$ & $17.85^{* * *}$ \\
\hline Heel-to-instep circumference & $328.60^{a}$ & $330.74^{a}$ & $339.43^{b}$ & $21.82^{* * *}$ \\
\hline Heel-to-ankle circumference & $298.29^{a}$ & $303.25^{b}$ & $311.61^{c}$ & $40.79^{* * *}$ \\
\hline Ball height & $33.16^{a}$ & $33.79^{a}$ & $34.91^{b}$ & $17.41^{* * *}$ \\
\hline Toe 1 height & $21.43^{a}$ & $22.42^{b}$ & $22.95^{c}$ & $21.63^{* * *}$ \\
\hline Toe 5 angle ${ }^{a}$ & $11.17^{b}$ & 10.92 & 10.76 & 0.37 \\
\hline$p \leq .05, p \leq 01,0$ & & & 2 \\
\hline
\end{tabular}

${ }^{*} p \leq .05,{ }^{* * *} p \leq .001$, Duncan's test: $\mathrm{a}<\mathrm{b}<\mathrm{c}$ 
과 과체중군보다 적게 나타나, 다른 체중군에 비해 새끼발가락이 곧게 뻗은 형태라 할 수 있다. 비만군 은 전체적인 계측 항목에서 발 크기와 둘레 등이 가 장 큰 것으로 나타나, 발이 체중과 비례하여 두껍고 크다는 것을 알 수 있다.

\section{Development of standard shoe-last}

1) Development of standard shoe-last of normal weight

여성 시니어 세대 정상체중군의 표준 라스트를 제 작하기 위한 라스트의 항목별 설계값을 도출하기 위 해 발길이를 독립변수 $(\mathrm{x})$ 로 하여 각각의 항목을 종속 변수(y)로 회귀식을 구하였다. 발길이에 대한 설계 항 목별 관련성을 검증한 결과, 새끼발가락측각도를 제 외한 나머지 모든 항목에서 유의한 결과로 나타났다. 도출된 회귀식은 〈Table 4〉와 같다. 정상체중군의 표 준 라스트 개발을 위해 관련성이 없는 새끼발가락측
각도를 제외한 $235 \mathrm{~mm}$ 사이즈의 항목별 설계값을 도 출하였으며, 원활한 라스트 설계를 위해 설계값을 소 수점 1자리로 정하였다. 회귀식을 통해 도출한 정상 체중군의 라스트 설계값 및 편차는 〈Table 5〉와 같다. 발꿈치-발등길이는 $129.9 \mathrm{~mm}$, 발꿈치-발목길이 $99.1 \mathrm{~mm}$ 는 큰 편차를 보였으며, 볼높이 $33.5 \mathrm{~mm}$, 엄지발가락 높이 $21.7 \mathrm{~mm}$ 로서 모든 항목 중 가장 적은 편차를 보 였다.

회귀식을 통해 도출된 항목별 설계값과 한국산업 규격 KS G 3405 라스트를 적용하여 $235 \mathrm{~mm}$ 여성 시 니어 세대 정상체중군의 표준 라스트를 개발한 결과 는 〈Fig. 1〉과 같다.

개발된 라스트의 분석을 위해 저면부를 기준으로 한 길이와 너비, 둘레항목 등을 측정하여 라스트 형 태에 대한 기준값을 측정하였다. 정상체중군 표준 라 스트의 $235 \mathrm{~mm}$ 사이즈 총 길이는 신발 제작을 위한 토박스가 추가된 $246 \mathrm{~mm}$ 이며, 굽높이는 $30 \mathrm{~mm}$, 토스 프링은 $9 \mathrm{~mm}$ 로 개발되었다. 뒤꿈치너비는 $62.6 \mathrm{~mm}$ 로

$<$ Table 4> Regression equation by item of normal weight

\begin{tabular}{|c|c|c|}
\hline Independent variable $(x)$ & Dependent variable $(y)$ & Regression equation \\
\hline \multirow{15}{*}{ Foot length } & Heel-to-instep length & $y=0.491^{* * *} \times x+14.552$ \\
\hline & Heel-to-ankle length & $y=0.408^{* * *} \times x+3.227$ \\
\hline & Foot breadth & $y=0.303^{* * *} \times x+21.528$ \\
\hline & Ball distance & $y=0.300^{* * *} \times x+25.164$ \\
\hline & Medial ball width & $y=0.187^{* * *} \times x+0.430$ \\
\hline & Lateral ball width & $y=0.109^{* *} \times x+22.730$ \\
\hline & Heel width & $y=0.175^{* * *} \times x+21.384$ \\
\hline & Ball circumference & $y=0.562^{* * *} \times x+97.509$ \\
\hline & Instep circumference & $y=0.581^{* * *} \times x+87.336$ \\
\hline & Perpendicular ankle circumference & $y=0.590^{* * *} \times x+105.011$ \\
\hline & Heel-to-instep circumference & $y=1.067^{* * *} \times x+84.355$ \\
\hline & Heel-to-ankle circumference & $y=0.907^{* * *} \times x+90.598$ \\
\hline & Ball height & $y=0.065^{* *} \times x+18.200$ \\
\hline & Toe 1 height & $y=0.036^{*} \times x+13.271$ \\
\hline & Toe 5 angle & $y=0.069 \times x-4.586$ \\
\hline
\end{tabular}

${ }^{*} p \leq .05,{ }^{* *} p \leq .01,{ }^{* * *} p \leq .001$ 
$<$ Table 5> Design values and deviations of normal weight standard shoe-last

(unit: $\mathrm{mm}$ )

\begin{tabular}{c|l|c|c}
\hline \multicolumn{1}{c|}{ Size } & \multicolumn{1}{|c|}{ Design item } & Design values & 2.455 \\
\hline \multirow{4}{*}{ Heel-to-instep length } & 129.9 & 2.040 \\
\cline { 2 - 4 } & Heel-to-ankle length & 99.1 & 1.515 \\
\cline { 2 - 4 } & Foot breadth & 92.7 & 1.500 \\
\cline { 2 - 4 } & Ball distance & 95.7 & 0.935 \\
\cline { 2 - 4 } & Medial ball width & 44.4 & 0.545 \\
\cline { 2 - 4 } & Lateral ball width & 48.3 & 0.875 \\
\cline { 2 - 4 } & Heel width & 62.5 & 2.810 \\
\cline { 2 - 4 } & Ball circumference & 229.6 & 2.905 \\
\cline { 2 - 4 } & Instep circumference & 223.9 & 2.950 \\
\cline { 2 - 4 } & Perpendicular ankle circumference & 243.7 & 5.335 \\
\cline { 2 - 4 } & Heel-to-instep circumference & 335.1 & 4.535 \\
\hline & Heel-to-ankle circumference & 303.7 & 0.325 \\
\hline
\end{tabular}

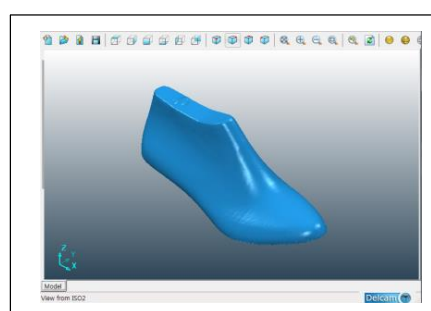

Isometric view 1

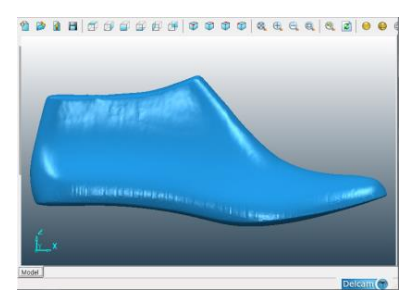

Right view

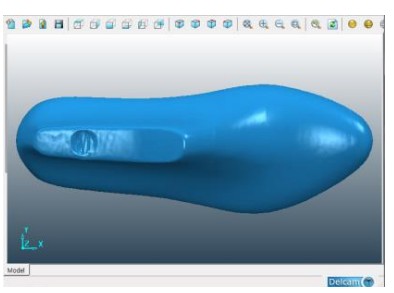

Top view

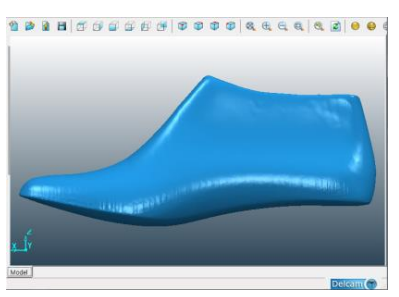

Left view

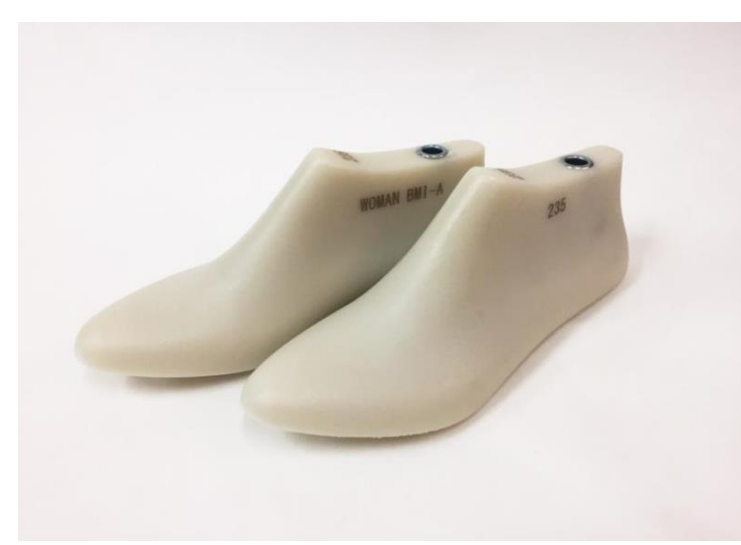

Normal weight standard shoe-last

<Fig. 1> Normal weight standard shoe-last

나타났으며, 발목수직둘레 $276.4 \mathrm{~mm}$, 발등수직둘레 $246.8 \mathrm{~mm}$, 볼수직둘레 $224.6 \mathrm{~mm}$ 로 나타났다. 발저면 너비는 $87.6 \mathrm{~mm}$, 볼저면거리 $88.7 \mathrm{~mm}$, 내측볼저면너 비 $38.5 \mathrm{~mm}$, 외측볼저면너비 $49.1 \mathrm{~mm}$, 뒤꿈치저면너 비 $59.2 \mathrm{~mm}$, 뒤꿈치-안쪽점저면길이 $168.0 \mathrm{~mm}$, 뒤꿈 치-가쪽점저면길이 $154.1 \mathrm{~mm}$ 로 나타났다.

\section{2) Development of standard shoe-last of over} weight

과체중군의 표준 라스트를 제작하기 위한 라스트 의 항목별 설계값을 도출하기 위해 발길이를 독립변 수(x)로 하여 각각의 항목을 종속변수(y)로 회귀식을 구하였다. 발길이에 대한 설계 항목별 관련성을 검증 
<Table 6> Regression equation by item of overweight

\begin{tabular}{|c|c|c|}
\hline Independent variable $(x)$ & Dependent variable $(y)$ & Regression equation \\
\hline \multirow{15}{*}{ Foot length } & Heel-to-instep length & $y=0.541^{* * *} \times x+2.561$ \\
\hline & Heel-to-ankle length & $y=0.4466^{* * *} \times x-4.056$ \\
\hline & Foot breadth & $y=0.2846^{* * *} \times x+28.067$ \\
\hline & Ball distance & $y=0.309^{* * *} \times x+25.125$ \\
\hline & Medial ball width & $y=0.161^{* *} \times x+7.785$ \\
\hline & Lateral ball width & $y=0.122^{* *} \times x+20.487$ \\
\hline & Heel width & $y=0.185^{* * *} \times x+19.906$ \\
\hline & Ball circumference & $y=0.685^{* * *} \times x+74.404$ \\
\hline & Instep circumference & $y=0.491^{* * *} \times x+113.045$ \\
\hline & Perpendicular ankle circumference & $y=0.534^{* *} \times x+122.948$ \\
\hline & Heel-to-instep circumference & $y=1.157^{* * *} \times x+65.970$ \\
\hline & Heel-to-ankle circumference & $y=0.976^{* * *} \times x+79.890$ \\
\hline & Ball height & $y=0.057^{*} \times x+20.762$ \\
\hline & Toe 1 height & $y=0.013 \times x+19.379$ \\
\hline & Toe 5 angle & $y=0.084^{*} \times x-8.400$ \\
\hline
\end{tabular}

${ }^{*} p \leq .05,{ }^{* *} p \leq .01,{ }^{* * *} p \leq .001$

한 결과, 엄지발가락높이를 제외한 모든 항목이 유의 하게 나타났다. 항목별 회귀식은 〈Table 6)과 같다.

과체중군의 표준 라스트 개발을 위해 관련성이 없 는 엄지발가락높이를 제외한 $235 \mathrm{~mm}$ 사이즈의 항목 별 설계값을 구하였으며, 원활한 라스트 설계를 위해 설계값을 소수점 1 자리로 정하였다. 과체중군의 라스 트 설계값 및 편차는 〈Table 7〉과 같다. 발꿈치-발등 둘레 $337.9 \mathrm{~mm}$ 와 발꿈치-발목수직둘레 $309.3 \mathrm{~mm}$ 에서 큰 편차를 보였으며, 새끼발가락측각도 $11.3^{\circ}$ 와 볼 높이 $34.2 \mathrm{~mm}$ 가 모든 항목 중 가장 적은 편차를 보였 다.

회귀식을 통해 도출된 항목별 설계값과 한국산업 규격 KS G 3405 라스트를 적용하여 $235 \mathrm{~mm}$ 여성 시 니어 세대 과체중군의 표준 라스트를 개발한 결과는 〈Fig. 2〉와 같다.

개발된 라스트의 분석을 위해 저면부를 기준으로 한 길이와 너비, 둘레항목 등을 측정하여 라스트 형 태에 대한 기준값을 측정하였다. 과체중군 표준 라스
트 $235 \mathrm{~mm}$ 사이즈의 라스트 총 길이는 신발 제작을 위한 토박스가 추가된 $246 \mathrm{~mm}$ 이며, 굽높이는 $30 \mathrm{~mm}$, 토스프링은 $9 \mathrm{~mm}$ 로 개발되었다. 뒤꿈치너비는 63.9 $\mathrm{mm}$ 로 나타났으며, 발목수직둘레 $284.3 \mathrm{~mm}$, 발등수직 둘레 $253.0 \mathrm{~mm}$, 볼수직둘레 $229.3 \mathrm{~mm}$ 로 나타났다. 발 저면너비는 $90.1 \mathrm{~mm}$, 볼저면거리 $91.3 \mathrm{~mm}$, 내측볼저 면너비 $39.4 \mathrm{~mm}$, 외측볼저면너비 $50.7 \mathrm{~mm}$, 뒤꿈치저 면너비 $60.2 \mathrm{~mm}$, 뒤꿈치-안쪽점저면길이 $169.0 \mathrm{~mm}$, 뒤꿈치-가쪽점저면길이 $154.5 \mathrm{~mm}$ 로 나타났다.

\section{3) Development of standard shoe-last of obesity}

비만군의 표준 라스트를 제작하기 위한 라스트의 설계값을 도출하기 위해 발길이를 독립변수 $(x)$ 로 하 여 각각의 항목을 종속변수 $(y)$ 로 회귀식을 구하고, 발길이에 대한 항목별 관련성을 검증한 결과, 엄지발 가락높이와 새끼발가락측각도를 제외한 모든 항목에 서 유의하게 나타났다. 발길이에 대한 항목별 회귀식 은 〈Table 8 과 같다. 


\begin{tabular}{c|l|c|c}
\hline \multicolumn{1}{c|}{ Size } & \multicolumn{1}{|c|}{ Design item } & Design values & Deviations \\
\hline & Heel-to-instep length & 129.7 & 2.705 \\
\cline { 2 - 4 } & Heel-to-ankle length & 100.8 & 1.420 \\
\cline { 2 - 4 } & Foot breadth & 94.8 & 1.545 \\
\cline { 2 - 4 } & Ball distance & 97.7 & 0.805 \\
\cline { 2 - 4 } & Medial ball width & 45.6 & 0.610 \\
\cline { 2 - 4 } & Lateral ball width & 49.2 & 0.925 \\
\cline { 2 - 4 } & Heel width & 63.4 & 3.425 \\
\cline { 2 - 4 } & Ball circumference & 235.4 & 2.455 \\
\cline { 2 - 4 } & Instep circumference & 228.4 & 2.670 \\
\cline { 2 - 4 } & Perpendicular ankle circumference & 238.4 & 5.785 \\
\cline { 2 - 4 } & Heel-to-instep circumference & 337.9 & 4.880 \\
\cline { 2 - 4 } & Heel-to-ankle circumference & 309.3 & 0.285 \\
\cline { 2 - 4 } & Ball height & 34.2 & 0.420 \\
\hline
\end{tabular}

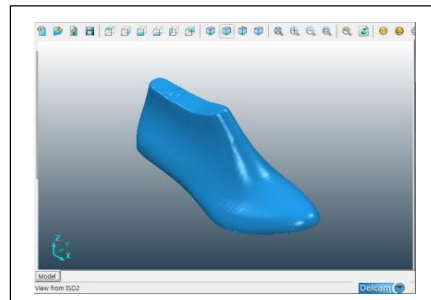

Isometric view

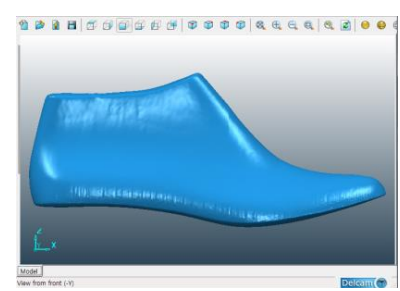

Right view

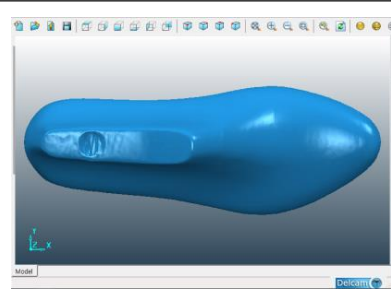

Top view

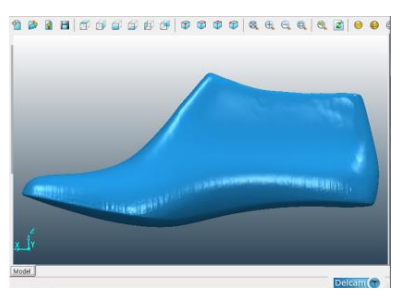

Left view

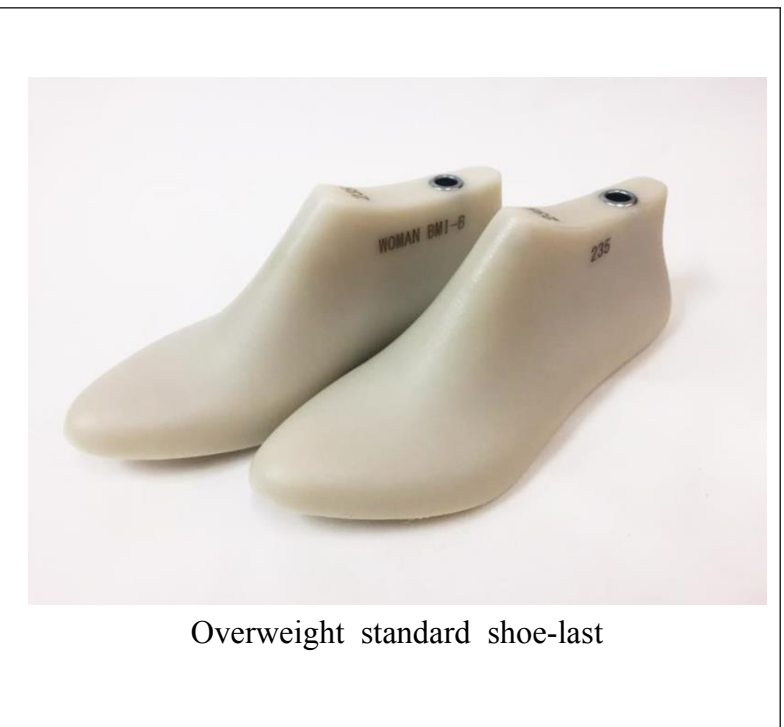

<Fig. 2> Overweight standard shoe-last
비만군의 표준 라스트 개발을 위해 관련성이 없다 고 나타난 엄지발가락높이와 새끼발가락측각도를 제 외한 $235 \mathrm{~mm}$ 사이즈의 항목별 설계값을 구하였으며, 원활한 라스트 설계를 위해 설계값을 소수점 1자리로 정하였다. 비만군의 라스트 설계값 및 편차는〈Table
9>와 같다. 발꿈치-발등둘레 $343.5 \mathrm{~mm}$ 와 외측볼너비 $49.7 \mathrm{~mm}$ 항목에서 가장 큰 편차를 보였으며, 볼높이 $35.0 \mathrm{~mm}$ 로서 모든 항목 중 가장 적은 편차를 보였다. 회귀식을 통해 도출된 항목별 설계값과 한국산업 규격 KS G 3405 라스트를 적용하여 $235 \mathrm{~mm}$ 여성 시 
<Table 8> Regression equation by item of obesity

\begin{tabular}{|c|c|c|}
\hline Independent variable $(x)$ & Dependent variable $(y)$ & Regression equation \\
\hline \multirow{15}{*}{ Foot length } & Heel-to-instep length & $y=0.544^{* * *} \times x+4.373$ \\
\hline & Heel-to-ankle length & $y=0.436^{* * *} \times x-1.189$ \\
\hline & Foot breadth & $y=0.268^{* * *} \times x+31.708$ \\
\hline & Ball distance & $y=0.300^{* * *} \times x+27.658$ \\
\hline & Medial ball width & $y=0.195^{* * *} \times x-0.771$ \\
\hline & Lateral ball width & $y=0.074^{*} \times x+32.260$ \\
\hline & Heel width & $y=0.205^{* * *} \times x+16.294$ \\
\hline & Ball circumference & $y=0.627^{* * *} \times x+89.744$ \\
\hline & Instep circumference & $y=0.508^{* * *} \times x+111.816$ \\
\hline & Perpendicular ankle circumference & $y=0.516^{* * *} \times x+133.541$ \\
\hline & Heel-to-instep circumference & $y=1.233^{* * *} \times x+53.719$ \\
\hline & Heel-to-ankle circumference & $y=1.028^{* * *} \times x+73.423$ \\
\hline & Ball height & $y=0.055^{* *} \times x+22.088$ \\
\hline & Toe 1 height & $y=0.022 \times x+17.859$ \\
\hline & Toe 5 angle & $y=-0.004 \times x+11.782$ \\
\hline
\end{tabular}

${ }^{*} p \leq .05,{ }^{* *} p \leq .01,{ }^{* * *} p \leq .001$

$<$ Table 9> Design values and deviations of obesity standard shoe-last

(unit: $\mathrm{mm}$ )

\begin{tabular}{l|l|c|c}
\hline \multicolumn{1}{c|}{ Size } & \multicolumn{1}{|c|}{ Design item } & Design values & 2.720 \\
\hline \multirow{5}{*}{$235 \mathrm{~mm}$} & Heel-to-instep length & 132.2 & 2.180 \\
\cline { 2 - 4 } & Heel-to-ankle length & 101.3 & 1.330 \\
\cline { 2 - 4 } & Foot breadth & 94.2 & 1.500 \\
\cline { 2 - 4 } & Ball distance & 98.2 & 0.975 \\
\cline { 2 - 4 } & Medial ball width & 45.1 & 0.370 \\
\cline { 2 - 4 } & Lateral ball width & 49.7 & 1.025 \\
\cline { 2 - 4 } & Heel width & 64.5 & 3.135 \\
\cline { 2 - 4 } & Ball circumference & 237.1 & 2.540 \\
\cline { 2 - 4 } & Instep circumference & 231.2 & 2.580 \\
\cline { 2 - 4 } & Perpendicular ankle circumference & 254.8 & 6.165 \\
\cline { 2 - 4 } & Heel-to-instep circumference & 343.5 & 5.140 \\
\cline { 2 - 4 } & Heel-to-ankle circumference & 315.0 & 0.275 \\
\cline { 2 - 4 } & Ball height & 35.0 & 2.0 \\
\hline
\end{tabular}




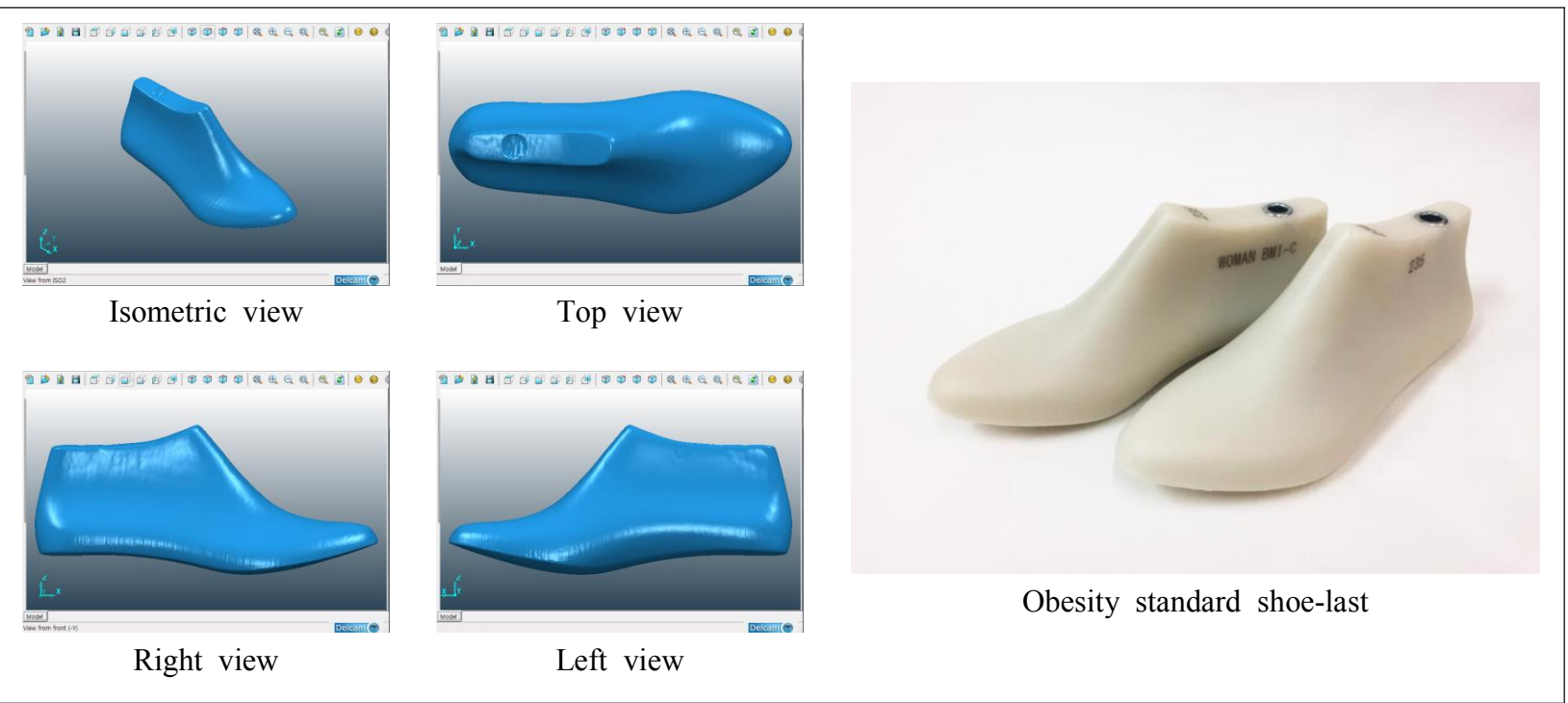

<Fig. 3> Obesity standard shoe-last

니어 세대 비만군의 표준 라스트를 개발한 결과는 〈Fig. 3〉과 같다.

개발된 비만군 표준 라스트의 분석을 위해 저면부 를 기준으로 한 길이와 너비, 둘레항목 등을 측정하 여 라스트 형태에 대한 기준값을 측정하였다. 비만군 표준 라스트 $235 \mathrm{~mm}$ 사이즈의 라스트 총 길이는 토 박스가 추가된 $246 \mathrm{~mm}$ 이며, 굽높이는 $30 \mathrm{~mm}$, 토스프 링은 $9 \mathrm{~mm}$ 로 개발되었다. 뒤꿈치너비는 $64.6 \mathrm{~mm}$ 로 나타났으며, 발목수직둘레 $285.4 \mathrm{~mm}$, 발등수직둘레 $254.8 \mathrm{~mm}$, 볼수직둘레 $231.1 \mathrm{~mm}$ 로 나타났다. 발저면 너비는 $90.3 \mathrm{~mm}$, 볼저면거리 $91.7 \mathrm{~mm}$, 내측볼저면너 비 $39.6 \mathrm{~mm}$, 외측볼저면너비 $50.7 \mathrm{~mm}$, 뒤꿈치저면너 비 $60.5 \mathrm{~mm}$, 뒤꿈치-안쪽점저면길이 $169.1 \mathrm{~mm}$, 뒤꿈 치-가쪽점저면길이 $153.3 \mathrm{~mm}$ 로 나타났다.

\section{Comparative analysis of standard shoe-last}

\section{1) Comparative analysis of measured items}

본 연구결과를 통해 개발된 여성 시니어 세대의 정 상체중, 과체중 및 비만 집단의 표준 라스트와 비교 라스트를 분석하기 위해 "EasyLast3D"와 "Vernier calipers"를 사용하여 항목별 기준값을 살펴보았으며, 그 결과는〈Table 10 〉과 같다.

$235 \mathrm{~mm}$ 사이즈 라스트의 총 길이는 $246 \mathrm{~mm}$ 로 동 일하게 개발되었으며, 굽높이 $30 \mathrm{~mm}$ 와 토스프링 9 $\mathrm{mm}$ 도 동일하게 개발되었다. 비교라스트와 가장 큰
편차를 나타낸 항목은 발목수직둘레 항목으로 정상 체중군은 $26.6 \mathrm{~mm}$ 의 편차를 보였으며, 비만군은 35.6 $\mathrm{mm}$ 의 큰 차이를 나타냈다. 이어서 발등수직둘레, 볼 수직둘레 항목이 큰 편차로 나타났으며, 정상체중군 에 비해 비만군의 발목수직둘레가 최대 $9 \mathrm{~mm}$ 의 차이 를 보였다. 뒤꿈치 너비는 비만군의 표준 라스트가 비교라스트에 비해 $7.8 \mathrm{~mm}$ 나 넓은 것으로 나타나, 여 성시니어 세대 비만군이 비교라스트로 제작된 신발 을 신었을 때 좁은 뒤꿈치로 큰 불편함을 느낄 것으 로 사료되며, 지면에 닿는 면적이 줄어들어 밸런스를 잡기에 어려울 것으로 보인다. 발저면너비와 볼저면 거리에서 모두 비교라스트보다 $14 \mathrm{~mm} 18 \mathrm{~mm}$ 의 큰 차이를 기록하였으며, 비만군의 경우 발저면너비가 비교라스트와 $18 \mathrm{~mm}$ 이상 편차가 있는 것으로 나타 나, 비만군이 비교라스트로 제작된 신발을 착화하였 을 경우, 발의 통증과 함께 발의 무지외반증과 같은 변형이 생길 수 있을 것으로 사료된다. 이는 비교라 스트가 여성 시니어 세대의 발에는 맞지 않는다는 것 을 단적으로 보여주는 결과라 할 수 있으며, $\mathrm{BMI}$ 군 에 따라 각자의 발에 맞는 신발을 착화해야 할 것으 로 사료된다.

여성 시니어 세대의 표준 라스트는 BMI군에 따라 항목별 모두 다른 수치를 나타내고 있으며, 특히 너 비항목과 둘레항목에서 큰 차이를 나타내고 있다. 이 는 성인과 시니어 세대의 구분뿐만 아니라, 세대에 따라 세분화되고, 전문적인 신발 상품을 위한 분류가 
$<$ Table 10> Comparison of standard shoe measurement items

(unit: $\mathrm{mm}$ )

\begin{tabular}{|c|c|c|c|c|c|}
\hline & Shoe-last size & \multicolumn{4}{|c|}{235} \\
\hline & Measurement items & $\begin{array}{l}\text { Comparative } \\
\text { shoe-last }\end{array}$ & $\begin{array}{l}\text { Normal } \\
\text { weight }\end{array}$ & Overweight & Obesity \\
\hline \multirow{4}{*}{ EasyLast3D } & Heel width & 56.8 & 62.6 & 63.9 & 64.6 \\
\hline & Perpendicular ankle circumference & 249.8 & 276.4 & 284.3 & 285.4 \\
\hline & Perpendicular instep circumference & 224.4 & 246.8 & 253.0 & 254.8 \\
\hline & Perpendicular ball circumference & 206.6 & 224.6 & 229.3 & 231.1 \\
\hline \multirow{10}{*}{$\begin{array}{l}\text { Vernier } \\
\text { calipers }\end{array}$} & Total length & 246 & 246 & 246 & 246 \\
\hline & Heel height & 30 & 30 & 30 & 30 \\
\hline & Toe spring & 9 & 9 & 9 & 9 \\
\hline & Foot bottom width & 72 & 87.6 & 90.1 & 90.3 \\
\hline & Foot bottom distance & 74 & 88.7 & 91.3 & 91.7 \\
\hline & Medial ball bottom width & 33 & 38.5 & 39.4 & 39.6 \\
\hline & Lateral ball bottom width & 39 & 49.1 & 50.7 & 50.7 \\
\hline & Heel bottom width & 48 & 59.2 & 60.2 & 60.5 \\
\hline & Heel to tibiale bottom length & 164 & 168.0 & 169.0 & 169.1 \\
\hline & Heel-to-fibulare bottom length & 146 & 154.1 & 154.5 & 153.3 \\
\hline
\end{tabular}

필요함을 알 수 있으며, 이에 따라 신발 제작 시 사용 하는 라스트 또한 다르게 제작해야 할 필요성이 있다.

\section{2) 3D compare analysis of standard shoe-last}

개발된 여성 시니어 세대 표준 라스트와 비교 라스 트의 3D 분석을 위해 "Geomagic Qualify 12" 프로그 램을 통한 “3D compare" 방법으로 비교 분석을 실시 하였다. 비교 라스트를 기준 데이터로 정하고, BMI군 에 따른 각각의 라스트를 테스트 데이터로 지정하여 분석하였으며, 그 결과는 〈Fig. 4〉, 〈Fig. 5〉, 〈Fig. 6〉 과 같다.

여성 시니어 세대 정상체중군의 표준 라스트는 비 교 라스트에 비해 새끼발가락쪽 부위와 발볼부위, 뒤 꿈치부위에서 큰 편차를 나타냈다. 발볼은 $4 \mathrm{~mm}$ $6 \mathrm{~mm}$ 의 큰 차이를 보이고 있으며, 뒤꿈치너비 또한 $1 \sim 3 \mathrm{~mm}$ 이상의 차이를 보이고 있다. 안쪽보다 바깥쪽 발볼이 더욱 넓게 차이가 나고, 최대 $6 \mathrm{~mm}$ 이상의 큰 차이를 보이고 있어, 비교 라스트와 큰 차이를 나타 내고 있다.
과체중군의 표준 라스트의 경우, 정상체중군과 흡 사한 형태로 비슷한 편차의 모양을 나타내고 있으나, 그 차이는 더욱 큰 것으로 나타났다. 발볼의 경우, $5 \mathrm{~mm} 8 \mathrm{~mm}$ 이상의 큰 편차를 보이고 있으며, 뒤꿈치 너비도 양쪽 모두 $3 \mathrm{~mm}$ 이상의 차이를 보여 비교 라 스트가 크게 적은 수치를 기록하였다. 이는 정상체중 군에 비해 더욱 큰 양상을 나타내고 있으며, 신발 제 작을 통한 착화에도 큰 영향을 미칠 것으로 사료된 다.

비만군 표준 라스트는 비교 라스트에 비해 발볼과 발등, 뒤꿈치 등 거의 모든 부위에서 편차를 보이고 있으며, 정상체중과 과체중군 라스트에 비해 발가락 높이에서 큰 편차를 나타내고 있다. 뒤꿈치너비의 경 우, 안쪽과 바깥쪽 모두 $3 \mathrm{~mm} 5 \mathrm{~mm}$ 의 큰 편차를 보이 고 있으며, 그 범위가 다른 $\mathrm{BMI}$ 군에 비해 더욱 넓게 나타났다. 발볼도 뒤꿈치너비와 마찬가지로 타 BMI 군에 비해 넓고 두꺼운 양상을 보였으며, 최대 $8 \mathrm{~mm}$ 의 차이를 보이며, 비교 라스트와의 차이를 나타냈다. 발등의 편차가 다른 BMI 군에 비해 더욱 크게 나타 


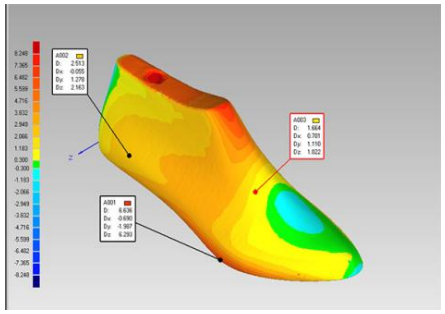

Isometric compare view 1

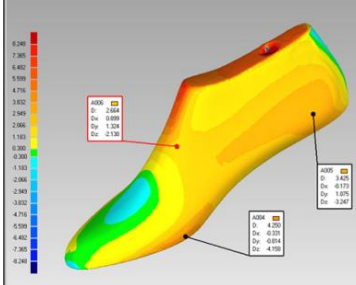

Isometric compare view 2

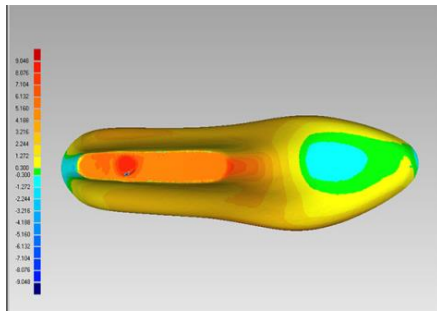

Top compare view

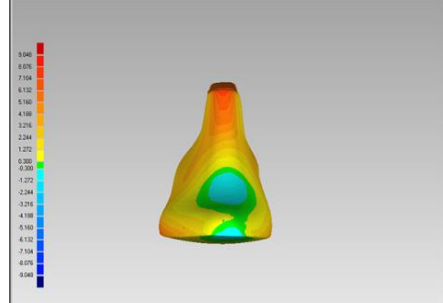

Front compare view

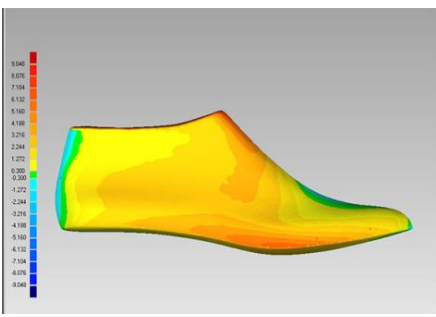

Outside compare view

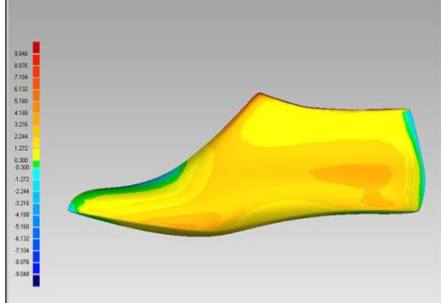

Inside compare view

$<$ Fig. 4> Normal weight 3D compare analysis

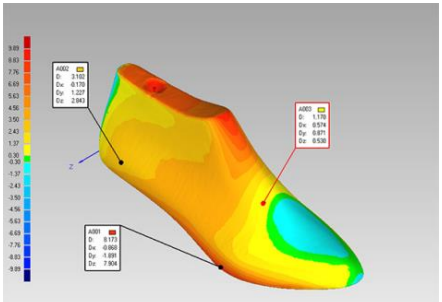

Isometric compare view 1

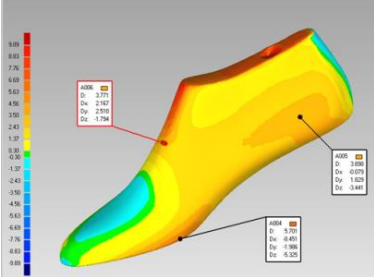

Isometric compare view 2

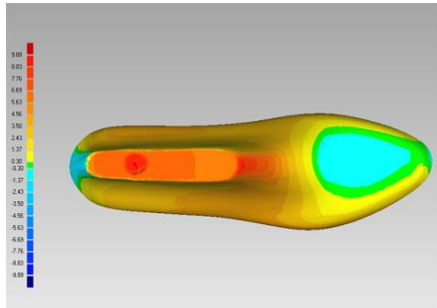

Top compare view

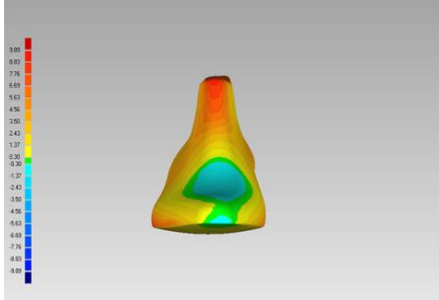

Front compare view

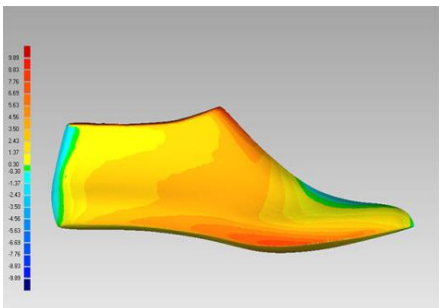

Outside compare view

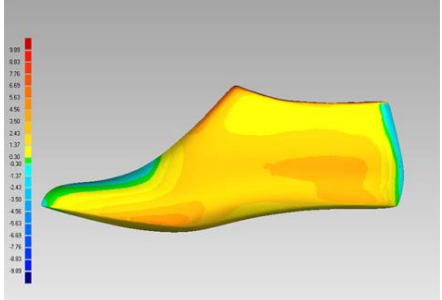

Inside compare view

<Fig. 5> Overweight 3D compare analysis

나고 있으며, 뒤꿈치까지 계속해서 이어지고 있음을 알 수 있다. 비교 라스트로 제작한 신발을 여성 시니 어 세대 비만군이 신을 경우, 발볼과 뒤꿈치 발등 등 신발의 모든 부위에서 압박을 받을 수 있음을 나타내 며, 발의 통증 및 변형을 가져올 수 있을 것으로 보인 다. 특히 발가락쪽에 나타난 편차는 발의 변형을 불 러일으킬 수 있는 중요한 부위이며, 계속해서 발에
맞지 않는 신발을 신을 경우, 무지외반증과 같은 질 병이 생길 수도 있어 시니어 세대를 위한 표준 라스 트로 제작한 신발의 도입이 시급한 실정이다. 또한, 작은 뒤꿈치너비로 제작된 신발을 신을 경우, 접지면 의 저하로 인해 좌우 밸런스에도 큰 흔들림이 생겨 낙상에 대한 위험도 올라갈 수 있어, 시니어 세대의 발에 잘 맞는 신발의 보급이 빠르게 이루어져야 할 


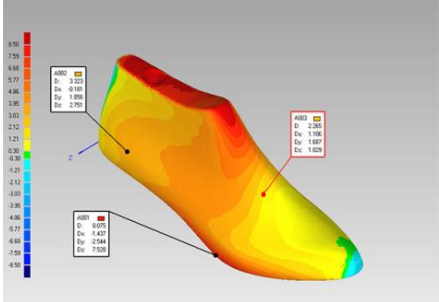

Isometric compare view 1

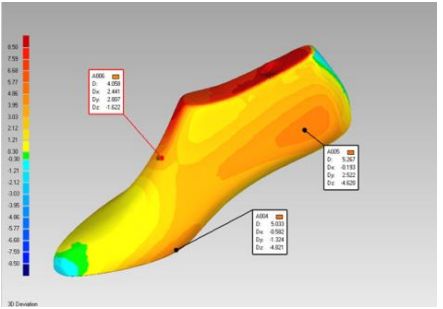

Isometric compare view 2

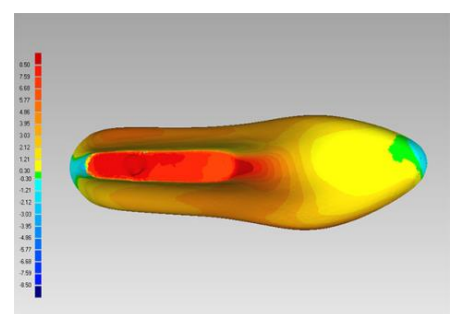

Top compare view

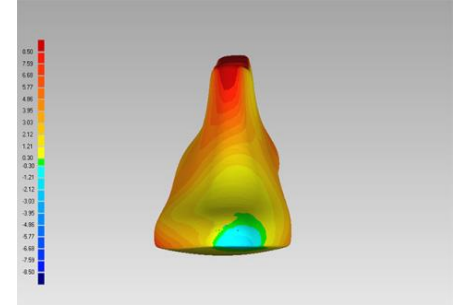

Front compare view

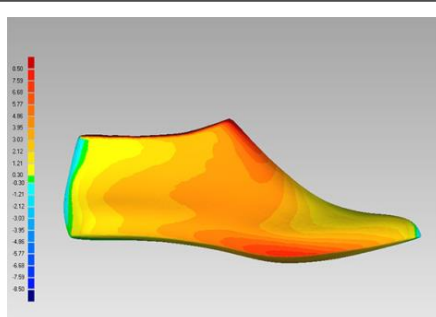

Outside compare view

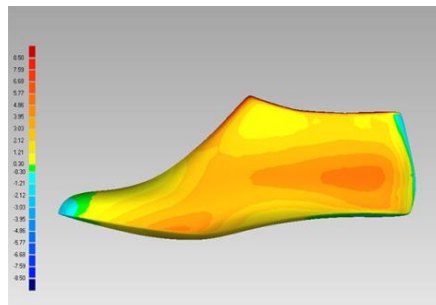

Inside compare view

<Fig. 6> Obesity 3D compare analysis

것으로 사료된다. 시니어 세대는 나이가 들수록 발의 변형이 더욱 크게 일어나고 있으며, 근육의 저하로 인해 일상생활이 어려워짐에 따라 낙상 등의 안전사 고가 발생할 확률이 늘어나고 있다. 이에 시니어 세 대의 안전한 생활을 위해 발에 맞는 신발 제작의 필 요성이 더욱 대두되고 있으며, 이를 위해 여성 시니 어 세대 BMI와 발의 특성에 따른 표준 라스트로 제 작된 신발의 활용이 더욱 중요할 것으로 사료된다.

\section{Conclusion}

현대사회의 시니어 세대는 경제적 발전과 함께 한 세대로서 과거에 비해 경제력과 시간을 가지고 다양 한 삶을 추구하고 있으며, 건강과 외모에 대한 관심 으로 다양한 의복을 요구하고 있어 패션유통업계의 주요 고객층으로 부상하고 있다. 패션 분야에서도 다 양한 의복 연구가 이루어지고 있으나, 대부분 발의 형태와 분류에 관한 연구만 이루어지고 있을 뿐, 시 니어 세대의 신발 제조를 위한 라스트 개발 연구는 미비한 실정이다. 이에 본 연구에서는 여성 시니어 세대의 안전한 생활을 위한 신발 제작의 전초 단계로 여성 시니어 세대의 BMI와 발의 특성에 따른 표준 라스트를 개발하고자 하였다. 이를 위해 50세 이상 여성 시니어 세대의 3 차원 발 형상 데이터를 활용하 였으며, 여성 시니어 세대를 BMI에 따라 분류하고,
항목별 기술통계와 분산분석, Duncan's test를 실시하 여 발의 특성을 분석하였다. 회귀식을 통해 항목별 라스트 설계값을 도출하고, 도출된 설계값을 적용하 여 여성 시니어 세대 BMI와 발 특성에 따른 표준 라 스트를 개발하였다. 본 연구의 결과를 요약하면 다음 과 같다.

첫째, 여성 시니어 세대의 BMI에 따른 발 특성 분 석을 위해 분산 분석과 Duncan's test를 실시한 결과, $\mathrm{BMI}$ 가 커질수록 발의 크기가 전반적으로 커지는 것 을 알 수 있었으며, 내측볼너비와 새끼발가락측각도 를 제외한 모든 항목에서 정상체중군과 과체중, 비만 군 세집단간 유의한 차이를 보였다. 이는 BMI에 따 라 체형뿐만 아니라, 발의 크기도 변화한다는 것을 나타내며, BMI에 따라서 의복 이외에 신발도 발에 맞게 신어야 할 것으로 사료된다.

둘째, 여성 시니어 세대 정상체중군의 표준 라스트 를 제작하기 위한 라스트의 항목별 설계값을 도출하 기 위해 발길이를 독립변수(x)로 하여, 각각의 항목을 종속변수(y)로 회귀식을 구하였다. 발길이에 대한 설 계 항목별 관련성을 검증한 결과, 새끼발가락측각도 를 제외한 나머지 모든 항목이 유의하게 나타났다. 이를 제외한 항목별 표준 라스트 설계값을 구하였으 며, 구해진 설계값을 적용하여 여성 시니어 세대 표 준 라스트를 개발하였다. 개발된 여성 시니어 세대 표준 라스트의 항목별 기준값을 측정한 결과, 라스트 
사이즈 $235 \mathrm{~mm}$, 라스트 총길이 $246 \mathrm{~mm}$, 굽높이 30 $\mathrm{mm}$, 토스프링 $9 \mathrm{~mm}$ 로 모두 동일하게 개발되었으며, 뒤꿈치-가쪽점저면길이를 제외한 모든 항목에서 비만 군이 가장 크게 나타났다.

셋째, 개발된 여성 시니어 세대 표준 라스트와 비 교라스트를 비교 분석한 결과, 개발된 표준라스트의 뒤꿈치너비가 $5.8 \mathrm{~mm} 7.8 \mathrm{~mm}$ 크게 나타나, 여성 시니 어 세대가 비교 라스트로 제작된 신발을 신었을 때 좁은 뒤꿈치로 인해 큰 불편을 느꼈을 것으로 사료되 며, 지면에 닿는 면적이 줄어들어 밸런스를 잡기에도 어려울 것으로 보인다. 둘레항목에서는 발목수직둘레 에서 $35.6 \mathrm{~mm}$ 의 큰 차이를 기록하였으며, 발너비와 볼거리에서 $4 \mathrm{~mm} \sim 18 \mathrm{~mm}$ 의 큰 차이를 기록하였다. 비 만군의 경우, 발저면너비가 $18 \mathrm{~mm}$ 이상 차이가 있는 것으로 나타나, 비만군이 비교 라스트로 제작된 신발 을 신을 경우, 발의 통증과 함께 발의 변형이 생길 수 있을 것으로 사료된다. 이는 한국표준협회에서 제공 하는 라스트가 여성 시니어 세대의 발에 맞지 않는다 는 것을 단적으로 보여주는 것이라 할 수 있으며, 시 니어 세대 표준 라스트의 활용이 더욱 필요한 것이라 할 수 있다.

넷째, 개발된 시니어 세대 표준 라스트를 "Geomagic Qualify 12" 프로그램을 활용하여 “3D Compare" 방식으로 분석한 결과, 너비와 둘레 등의 모든 부위 에서 비만군의 표준 라스트가 비교라스트에 비해 가 장 큰 편차를 보였다. 발가락쪽의 편차는 발의 변형 을 불러일으킬 수 있는 중요한 부위이며, 편차가 큰 라스트로 제작된 신발을 계속해서 신을 경우 무지외 반증과 같은 질병이 생길 수 있어, 시니어 세대 표준 라스트로 제작된 신발의 활용이 더욱 필요할 것으로 사료된다.

나이가 들며 힘이 없어지고 근육이 감소하는 시니 어 세대에게 있어서 신발은 보행의 밸런스를 맞춰 주 고, 안전한 일상생활을 할 수 있게 도와주는 중요한 요소이다. 나이가 들수록 체형과 발의 변형이 동반되 고, BMI에 따라 발의 크기도 변화되고 있어 이들의 체형과 발에 맞는 다양한 신발이 필요하다. 이에 시 니어 세대의 안전한 생활과 편안한 착화감을 위해 $\mathrm{BMI}$ 와 발 특성에 따른 표준 라스트를 활용한 세분화 된 신발 제작이 필요하다고 본다. 본 연구에서는 시 니어 세대의 $\mathrm{BMI}$ 와 발 특성에 따른 구두용 표준 라
스트를 개발하였으나, 실제 구두를 제작하여 착화 테 스트를 실시하지 않았다는 한계점이 있으며, 후속연 구로 $\mathrm{BMI}$ 와 발 특성을 적용한 라스트로 제작된 신발 의 제작 및 착화연구가 필요할 것으로 보인다. 개발 된 구두용 표준 라스트는 시니어 세대의 발에 적합한 신발의 제작 및 편안한 착화감의 향상과 함께 활발해 지고 있는 실버산업의 기초자료가 될 수 있을 것으로 기대한다.

\section{References}

Enforcement decree of the act on the employment of the aged. Korea Ministry of Government Legislation, Presidential Decree $\S 27751$ (2016).

Frey, C., Thompson, F., Smith, J., Sanders, M., \& Horstman, H. (1993). American orthopaedic foot and ankle society women's shoe survey. Foot \& Ankle International, 14(2), 78-81. doi:10.1177/ 107110079301400204

International Association for the Study of Obesity. (2000). The Asia-Pacific perspective: Redefining obesity and its treatment. Melbourne: Health communications Australia.

Kang, S.-W., \& Park, Y.-S. (2014). Difference of postural stability and gait by BMI level in the elderly. The Korean Journal of Growth and Development, 22(1), 61-66.

Kim, G.-D., Kim, S.-S., \& Han, G.-S. (2012). Kinematic analysis of weight distribution and stair descent gait motions between obese group and non obese group of elderly women. Journal of Coaching Development, 14(3), 95-104.

Kim, S.-A. (2011). Analysis and evaluation on buying orientations of shoes products based on selfimages of 40 50s' female consumers. Journal of Digital Interaction Design, 10(2), 33-44.

Kim, S.-A. (2016). Understanding shoes design (3rd ed.). Seoul: KSIF.

Kim, Y.-D. (2015). A case study on the development of insoles for seniors in preparation for aged society. Unpublished master's thesis, Hanbat Na- 
tional University, Daejeon, Korea.

Ko, B.-S. (2014). An analysis on senior's purchase decision-making on the internet shopping. Unpublished doctoral dissertation, Chung-Ang University, Seoul, Korea.

Ko, G. H. (2012). 고령친화산업 REPORT [Agedfriendly industry report]. Seoul: Veteran of Comrade in arms.

Ko, Y. J. (2007). Risk of hypertension by the body mass index in a middle-aged adults residence in Jejudo. Unpublished master's thesis, Jeju National University, Jeju Special Self-Governing Province, Korea.

Koreas Society for the Study of Obesity. (2012). 비 만치료 지침 2012 [Obesity treatment guidelines]. Seoul: Chungwoon.

Lee, J. Y. (2004). The investigation of the shoe-last size classification system for Korean adults with $3 D$ foot-scanner. Unpublished doctoral dissertation, Hanyang University, Seoul, Korea.

Lee, W. S. (2001). Development of shoelast design system using parametric modeling for shoe industry. Unpublished master's thesis, Seoul National University, Seoul, Korea.

Lee, W. S., \& Kim, S. A. (2016). Research trends on silver generation published in professional academic journal of clothing area. Journal of Integrated Design Research, 15(3), 53-62. doi:10. 21195/jdr.2016.15.3.005

Median age. (2016, March 14). In Wikipedia. Retrieved April 14, 2016, from https://ko.wikipedia. org/wiki/\%EC\%A4\%91\%EC\%9C\%84_\%EC\%97 $\%$ B $\%$ ЕB $\%$ A $\%$ B 9

New Silver Generation. (n.d.). In Doopedia. Retrieved June 13, 2016, from http://www.doopedia.co.kr/ doopedia/master/master.do?_method=view\&MAS IDX $=101013000877803$
Park, D. S., Kim, D. H., \& Lee, Y. S. (2003). 고령화 쇼크 [Aging shock]. Seoul: Goodinformation.

Park, J.-C. (2010). A study on the regional characteristics of elderly leisure activity in the aging society. Unpublished doctoral dissertation, Chonnam National University, Gwangju, Korea.

Park, J. K. (2003). Classification of foot types of elderly women and their characteristics. Unpublished doctoral dissertation, Seoul National University, Seoul, Korea.

Ryu, J. H., Park, J. H., \& Lee, Y. J. (2004). 노인 건 강생활과 호스피스 케어 [Elderly health life and hospice care]. Seoul: Hakmun.

Seong, D. H., Jung, E. S., \& Cho, Y. J. (2006). A study on the categorization of Korean foot shapes. Journal of the Ergonomics Society of Korea, 25(2), 107-118.

Shin, K.-J. (2008). A study on correlation of somatotype and foot classification. Unpublished master's thesis, Gangneung-Wonju National University, Gangwon-do, Korea.

Statistics Korea. (2015, July 8). 세계와 한국의 인구 현황 및 전망 [Demographics and prospects of the world and Korea]. Retrieved June 13, 2016, from http://kostat.go.kr/portal/korea/kor_nw/2/2/6/ index.board?bmode $=$ read\&aSeq $=347102$

Statistics Korea. (n.d.). National Indicator System. Retrieved August 5, 2016, from http://www.index. go.kr/potal/main/PotalMain.do

Toeslayer dot. (2009, October 30). Shoe lasts and metrology [Blog Post]. All about shoes, Retrieved July 19, 2016. from http://allaboutshoes-toeslayer. blogspot.kr/2009/10/shoe-lasts-and-metrology.html

Yun, Y. W. (2011). The relation between Body Mass Index and blood pressure in Korean young adults. Unpublished master's thesis, Chonnam National University, Gwangju, Korea. 